\title{
OPTIMALISASI APLIKASI CYREBORN DENGAN HTTPURLCONNECTION API BERBASIS FRAMEWORK DAN ANDROID UNTUK AUTENTIFIKASI PESERTA PKKMB
}

\author{
Andi Setiawan*1, Ahmad Fauzi ${ }^{2}$, Ade Irma Purnamasari ${ }^{3}$ \\ 1,2,3 STMIK IKMI Cirebon \\ Email: 142andisetiawan@gmail.com, 2fauzi.tikami@gmail.com, ${ }^{3}$ irma2974@yahoo.com \\ *Penulis Korespondensi
}

(Naskah masuk: 06 Februari 2020, diterima untuk diterbitkan: 08 Juni 2021)

\begin{abstract}
Abstrak
Aplikasi CyReborn merupakan sistem untuk memudahkan autentifikasi data peserta pengenalan kehidupan kampus mahasiswa baru atau PKKMB berbasis framework, namun mengalami kendala pada saat pengoperasinya, yaitu sulitnya menguraikan kepadatan antrian pada proses autentifikasi peserta terutama pada saat absensi pagi, absensi istirahat, dan absensi pulang. Tujuan penelitian dari penelitian ini adalah optimalisasi aplikasi CyReborn dengan HttpURLConnection API agar dapat menjalankan QRCode melalui aplikasi android pada bagian frontend, sedangkan pada bagian backend menggunakan web framework untuk pengelolaan data autentifikasinya. Sedangkan fokus dari penelitian ini adalah membandingkan kecepatan autentifikasi data peserta PKKMB, antara sebelum optimalisasi dengan yang sesudah dilakukan optimalisasi. Pengujian dilakukan dengan menggunakan empat API yang biasa digunakan pada aplikasi berbasis web PHP framework dan android, yaitu HttpURLConnection API, Retrofit API, OkHttp API dan Asynchronous Http Client API. Metode pengembangan perangkat lunak menggunakan Rapid Application Development (RAD), terdiri dari tiga tahap yaitu requirement planning, design system, dan implementation. Sedangkan data yang digunakan untuk pengujian sebanyak 117 peserta, dari jumlah populasi keseluruhan peserta sebanyak 248 peserta. Hasil yang diperoleh dari penelitian ini adalah kecepatan authentifikasi data peserta PKKMB aplikasi CyReborn dengan HttpURLConnection API, hasil terendah saat pengujian awal sebesar 30 detik dan tertinggi sebesar 90 detik, sedangkan hasil pengujian dengan HttpURLConnection API terendah sebesar 5 detik dan tertinggi 30 detik. Artinya hasil optimalisasi aplikasi CyReborn dengan HttpURLConnection API, meningkat sebesar 15 detik untuk hasil akhir terendah dan sebesar 82 detik untuk hasil akhir tertinggi, atau persentase terendah sebesar $40 \%$ dan persentase tertinggi $92 \%$.
\end{abstract}

Kata kunci: Aplikasi CyReborn, HttpURLConnection API, QRCode, Web Framework, Android.

\section{OPTIMIZATION OF CYREBORN APPLICATION WITH HTTPURLCONNECTION API BASED ON FRAMEWORK AND ANDROID FOR AUTHENTICATION OF PKKMB PARTICIPANTS}

\begin{abstract}
CyReborn application is a system to facilitate the authentication of participant's introduction of campus life for new students or PKKMB based on the framework, but has problems when operating, which is the difficulty of deciphering the queue density in the participant's authentication process especially during morning attendance, rest absenteeism, and home absence. The research objective of this research is to optimize the CyReborn application with the HttpURLConnection API so that it can run QRCode through the android application on the frontend, while the backend uses a web framework for managing its authentication data. While the focus of this study is to compare the speed of PKKMB participant data authentication, between before optimization and after optimization. Testing is done by using four APIs that are commonly used on PHP framework and android webbased applications, namely the HttpURLConnection API, Retrofit API, OkHttp API and Asynchronous Http Client API. The software development method uses Rapid Application Development (RAD), consisting of three stages, namely requirements planning, system design, and implementation. While the data used for testing were 117 participants, out of a total population of 248 participants. The results obtained from this study are the speed of authentication of PKKMB CyReborn application participants with the HttpURLConnection API, the lowest results at initial testing were 30 seconds and the highest was 90 seconds, while the test results with the lowest HttpURLConnection API were 5 seconds and the highest was 30 seconds. This means that the optimization results of the CyReborn application with the HttpURLConnection API, increase by 15 seconds for the lowest
\end{abstract}


final result and by 82 seconds for the highest final result, or the lowest percentage by $40 \%$ and the highest percentage by $92 \%$.

Keywords: CyReborn application, HttpURLConnection API, QRCode, Web framework, Android.

\section{PENDAHULUAN}

Kegiatan kuliah umum dan pengenalan kehidupan kampus mahasiswa baru atau PKKMB, rutin diselenggarakan setiap tahun khususnya pada saat mahasiswa baru dinyatakan diterima oleh pihak kampus dan sebelum dilaksanakannya perkuliahan. Jumlah peserta secara keseluruhan yang mengikuti kegiatan PKKMB berjumlah 248 orang mahasiswa, terdiri dari 182 orang calon mahasiswa jurusan Teknik Informatika jenjang studi strata-1, 22 orang calon mahasiswa jurusan Manajemen Informatika jenjang studi Diploma III, dan 44 calon mahasiswa jurusan Komputerisasi Informatika jenjang studi Diploma III. Untuk mendukung kegiatan tersebut, dikembangkan aplikasi CyReborn untuk membantu dalam autentifikasi data peserta PKKMB, terutama untuk membantu setiap mentor dalam kegiatan tersebut. Jumlah mentor sebanyak sepuluh orang mentor, masing-masing mentor bertanggung jawab terhadap sepuluh sampai lima belas orang peserta PKKMB. Secara teknis pelaksanaan, setiap mentor diberikan akun agar dapat mengakses aplikasi CyReborn untuk proses autentifikasi setiap peserta PKKMB yang menjadi tanggung jawabnya. Namun pada pelaksanaannya terjadi hambatan, terutama pada saat proses autentifikasi data peserta PKKMB. Hambatan tersebut berupa penumpukan peserta PKKMB yang diakibatkan sulitnya menguraikan kepadatan antrian pada saat proses autentifikasi peserta terutama pada saat absensi pagi, absensi istirahat, dan absensi pulang. Penumpukan peserta terjadi ketika data peserta yang harus diautentifikasi, kemudian dilanjutkan dengan proses penyimpanan kedalam database aplikasi CyReborn, harus diinputkan satu per satu menggunakan keyboard yang dioperasikan melalui laptop oleh setiap mentor, hal tersebut membutuhkan waktu yang cukup lama dan menjadi kendala dari aplikasi CyReborn pada saat dioperasikan terutama penumpukan peserta PKKMB pada saat masuk, istirahat, dan pulang.

Salah satu upaya yang dapat dilakukan dalam penelitian ini adalah dengan mengoptimalkan kembali aplikasi CyReborn yang sudah diimplementasikan pada kegiatan PKKMB dengan menambahkan HttpURLConnection API agar dapat mengeksekusi $Q R$-Code berbasis android dan web framework, untuk memudahkan pada proses autentifikasi data peserta PKKMB, kemudian data yang diperoleh dari QR-Code kemudian disimpan kedalam database dari aplikasi CyReborn.

HttpURLConnection API adalah sebuah library yang dikembangkan oleh java bersifat non-volatile yang digunakan untuk mengirimkan dan menerima data dari android ke PHP berbasis android networking berupa teks biasa, XML, JSON, gambar atau video streaming termasuk Quick Response Code atau QR-Code. Android akan mengakses HttpURLConnection, kemudian mengolah dan menyimpan data stream dari url tersebut (Azhar, Saudi, Ahmad, \& Abu Bakar, 2019).

Keunggulan dari library HttpURLConnection adalah penggunaan memori sangat kecil, yaitu sebesar 9748.4KB untuk teks, $18063.8 \mathrm{~KB}$ untuk teks dan gambar, sedangkan rata-rata penggunaan memori 13906.1KB, untuk library Asynchronous Http Client sebesar 10422.4KB untuk teks, $17984.6 \mathrm{~KB}$ untuk teks dan gambar, sedangkan ratarata penggunaan memori sebesar 14203.5KB, untuk library Retrofit sebesar $10385 \mathrm{~KB}$ untuk teks, 19267.4KB untuk teks dan gambar, sedangkan ratarata penggunaan memori sebesar $14826.2 \mathrm{~KB}$, dan untuk library OkHttp sebesar 10424.2KB untuk teks, $18186.8 \mathrm{~KB}$ untuk teks dan gambar, sedangkan ratarata penggunaan memori sebesar $14305.5 K B$, artinya apabila dibandingkan maka keunggulan dari implementasi library HttpURLConnection terletak pada penggunaan memori yang kecil dibandingkan dengan Asynchronous Http Client, Retrofit, dan OkHttp yang keempatnya merupakan library yang banyak digunakan aplikasi android dan web php (Ferryansyah, Ananta, \& Fanani, 2017).

Disamping keunggulan dalam penggunaan memori, keunggulan dari HttpURLConnection API lainnya adalah kecepatan dalam mengunduh dan mengunggah pada jaringan $W i F i$ dan $4 G$. Dari hasil percobaan menggunakan dua buah smartphone menunjukkan bahwa kinerja jaringan WiFi lebih baik dari jaringan 4G. Pengujian dilakukan dengan mengunggah file sebesar $8 \mathrm{MB}$ pada mode sinkron kecepatan antara 1300 - 1700 milisecond, sedangkan untuk mode asinkron kecepatan antara 1100 - 1300 milisecond. Sedangkan kecepatan saat mengunduh file sebesar $8 \mathrm{MB}$ pada mode sinkron sebesar 2000 2300 milisecond, sedangkan mode asinkron sebesar 800 - 1000 milisecond (Sufyan \& Banerjee, 2019).

Penelitian yang fokus pada pengembangan aplikasi menyebutkan bahwa dari 3,52\% aplikasi menggunakan library HttpURLConnection API, 19,6\% library retrofit API, dan 22,03\% library volley API. Library HttpURLConnection API lebih banyak digunakan untuk menangani aplikasi berbasis android dan web framework karena library HttpURLConnection API lebih banyak digunakan beserta library apache dengan keunggulan fitur seperti Post Request dan Multipart Uploads (Parmar, Patel, Agrawal, \& Verma, 2018).

Implementasi HttpURLConnection API pada aplikasi CyReborn dimaksudkan untuk memudahkan telepon pintar yang dimiliki oleh para mentor agar 
dapat mengenali informasi data peserta PKKMB yang telah terenkripsi oleh Quick Response Code atau QR-Code. Selain untuk memudahkan dalam mengenali informasi data peserta PKKMB, QRCode memiliki tingkat keamanan yang baik dalam mengenali pola gambar berupa cryp-graphic yang tercetak pada kartu tanda peserta PKKMB. Dari beberapa kasus percobaan menunjukkan $65,9 \%$ informasi yang tercetak pada QR-Code berhasil dikenali, sedangkan sisanya $25,6 \%$ informasi yang tercetak tidak dikenali. Hal tersebut terjadi akibat pola gambar memiliki kemiripan dengan pola gambar yang lain. Kemudian hasil luaran dari percobaan pertama, dievaluasi dan diperoleh hasil berupa 58,9\% menunjukkan hasil excellent, $\mathbf{2 7 , 9 \%}$ menunjukkan hasil good, dan $\mathbf{1 3 , 2 \%}$ menunjukkan hasil bad (Focardi, Luccio, \& Wahsheh, 2019). Disamping keunggulan dalam pengenalan pola gambar dan keunggulan enkripsi informasi data peserta PKKMB, implementasi Quick Response Code atau QR-Code mampu untuk menyimpan informasi yang lebih besar dibandingkan dengan kode sejenisnya berkonsep dua dimensi. Selain data berupa angka QR-Code mampu menampung semua jenis data yang dipresentasikan secara horizontal maupun vertikal, serta tahan terhadap kerusakan data sampai dengan 30\% bergantung versinya (Labolo, 2019). Disamping kemampuan untuk menampung semua jenis data, QR-Code dapat diimplementasikan dengan Augmented Reality baik teknik positioning, marker, dan markerless augmented reality services (Permana, Nurhayanti, \& Martono, 2016).

Aplikasi CyReborn dikembangkan dengan konsep model-view-controller atau web framework. Konsep framework telah teruji melalui penelitian yang memfokuskan pada kecepatan dari laravel framework dan slim framework. Pada mode received kecepatan framework laravel lebih baik dibandingkan dengan framework slim yaitu $384.11 \mathrm{~KB} /$ detik untuk untuk framework laravel dan $1151.03 \mathrm{~KB} /$ detik untuk framework slim. Sedangkan pada mode send kecepatan pengiriman untuk framework laravel sebesar $0,66 \mathrm{~KB} /$ detik sedangkan framework slim sebesar 1,79KB/detik (Sunardi \& Suharjito, 2019). Dukungan library dan JavaScript terhadap model, view, dan controller juga semakin kuat, yang ditujukan untuk memperhalus halaman front end dari framework, diantaranya adalah Backbone.js, Ember.js, React dan Flux, Meteor, AngularJS, dan sebagainya (Gracia \& Bayo, 2018). Dalam sebuah pengujian terhadap framework PhalconPHP dengan framework Symfony2, didapat hasil yang lebih baik PhalconPHP dibandingkan dengan framework Symfony2, yaitu untuk penanganan request PhalconPHP lebih baik sebesar 231,99 rps dibandingkan Symfony2 sebesar 49,33 rps (Prokofyeva \& Boltunova, 2017).

Tujuan dari penelitian ini adalah mengoptimalkan kembali kemampuan dari aplikasi CyReborn, digunakan untuk mendata peserta PKKMB, dengan menambahkan HttpURLConnection API, sebuah library yang dapat digunakan untuk menghubungkan antara aplikasi berbasis android dan web framework. Pengoperasian HttpURLConnection API, ditempuh agar dapat menjalankan $Q R$-Code melalui aplikasi android yang berada pada bagian frontend aplikasi CyReborn, untuk memudahkan proses autentifikasi pada saat pendataan absensi masuk, istirahat, dan pulang. Hasil autentifikasi yang diperoleh dari $Q R$ Code, kemudian direkam kedalam database $M y S Q L$ yang ada pada bagian backend aplikasi CyReborn untuk pengelolaan datanya. Penambahan HttpURL Connection API ditempuh agar fungsi $Q R$-Code yang ada pada bagian frontend dapat terhubung dengan web framework aplikasi CyReborn terutama pada bagian model untuk menghubungkan dengan database $M y S Q L$.

Sedangkan fokus penelitian adalah menentukan kecepatan autentifikasi data peserta PKKMB, antara sebelum dilakukan optimalisasi dengan sesudah dilakukan optimalisasi. Pengujian menggunakan empat buah $A P I$ sebagai pembanding dan banyak digunakan pada aplikasi berbasis web framework dan android, yaitu HttpURLConnection API, Retrofit API, OkHttp API dan Asynchronous Http Client API.

Data yang digunakan dalam pengujian pada penelitian ini adalah kecepatan pada saat proses autentifikasi, dengan satuan detik. Jumlah peserta yang digunakan dalam pengujian sebanyak 117 orang peserta, dari jumlah populasi keseluruhan peserta sebanyak 248 peserta dengan tingkat akurasi sebesar 92,5\% (Rono, 2018).

\section{METODE PENELITIAN}

Metode yang digunakan dalam penelitian ini adalah metode experimen (Supriyatman et al., 2018), dimulai dari pengujian kecepatan autentifikasi sebelum dilakukan optimalisasi dengan sesudah dilakukan optimalisasi dengan HttpURLConnection API, Retrofit API, OkHttp API dan Asynchronous Http Client API. Sedangkan untuk pemodelan sistem perangkat lunak yang digunakan dalam penelitian ini adalah Rapid Application Development (RAD), hal ini disebabkan karena Rapid Application Development $(R A D)$ memiliki siklus sistem yang singkat dibandingkan dengan pemodelan sistem lainnya, terdiri atas tiga tahap yaitu merencanakan kebutuhan sistem atau requirement planning yang dibutuhkan oleh kedua belah pihak, baik dari sisi pengguna atau para mentor maupun pengembang sistem. Kemudian tahap berikutnya adalah design system, pada tahap ini dibutuhkan komunikasi antara pengguna dan pengembang sistem untuk mendapatkan formulasi terbaik pada saat sistem mulai diimplementasikan. Sedangkan tahap terakhir adalah implementation, pada tahap ini aplikasi CyReborn yang sudah ditambahkan dengan library HttpURLConnection diuji coba dengan perangkat smartphone yang dimiliki oleh para mentor untuk mendapatkan 
keabsahan sistem (Faqih, Laksana, \& Febriati, 2018). Seperti pada gambar 1.

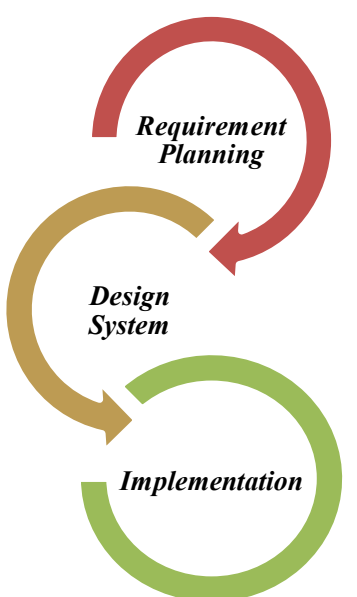

Gambar 1 Siklus Rapid Application Development (RAD)

Pemodelan perangkat lunak dengan medel rapid application development $(R A D)$, dinilai sangat tepat untuk diterapkan pada aplikasi CyReborn, hal ini disebabkan karena penggunaan kembali komponen atau aplikasi yang sudah ada yaitu aplikasi CyReborn, kemudian dimodifikasi kembali dengan library HttpURLConnection agar dapat berjalan pada platform android atau sering disebut dengan reusable object (Andri, 2019). Pengujian dalam penelitian ini menggunakan 4 (empat) buah API yang banyak digunakan aplikasi android dan web php, yaitu HttpURLConnection, Retrofit, OkHttp dan Asynchronous Http Client (Ferryansyah, Ananta, \& Fanani, 2017).

\section{HTTPURLCONNECTION DAN QR-CODE}

\subsection{HttpURLConnection API}

HttpURLConnection merupakan turunan dari class URLConnection dari java class abstrak, digunakan untuk berkomunikasi antara aplikasi android dengan web framework (Sufyan \& Banerjee, 2019), dalam hal ini aplikasi CyReborn. Berikut gambaran umum koneksi antara mentor dengan aplikasi CyReborn.
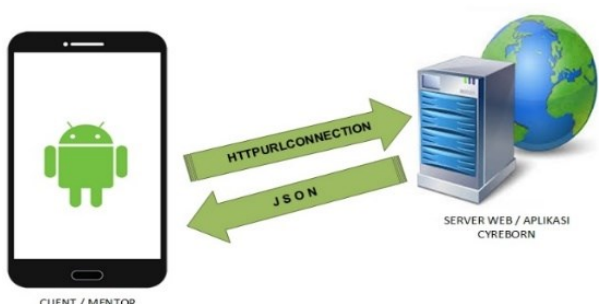

Gambar 2. Koneksi Secara Umum

Berikut urutan langkah yang harus ditempuh agar aplikasi CyReborn dapat dieksekusi oleh aplikasi android yang dimiliki oleh para mentor. a. Pengguna menekan tombol "Get Data", untuk memicu aksi "onclick listener", kemudian akan mengeksekusi dan menjalankan metode yang memproses HttpUrlConnection.

b. Metode yang memproses proses HttpUrl Connection akan meminta sumber data dari target url, kemudian menghubungkan koneksi ke server API.

c. Jika server mendapatkan permintaan dari http connection, server API akan merespon dengan mengirimkan data yang diminta.

d. Setelah server mengirimkan respon, metode http connection akan menangkap data stream yang dikirim secara langsung, membaca data stream melalui bufferreader(), kemudian akan menyimpan data string pada bufferreader(). Setelah data string dalam bufferreader() selesai dibaca, objek bufferreader() harus dikosongkan isinya dan koneksinya harus segera ditutup.

e. Kemudian metode httpconnection, akan segera menjalankan pada bagian dalam dari proses (asynctask), ketika metode httpconnection selesai diproses, selanjutnya hasil yang sudah diperoleh harus diproses terlebih dahulu sebelum dikirimkan ke user interface.

f. Langkah diatas kemudian dilanjutkan dengan merubah data, yaitu dari string menjadi objek JSON, setelah mengkonversi objek JSON berikutnya objek string ditambahkan ke textview. Berikut gambar yang dihasilkan dari beberapa langkah tersebut diatas.

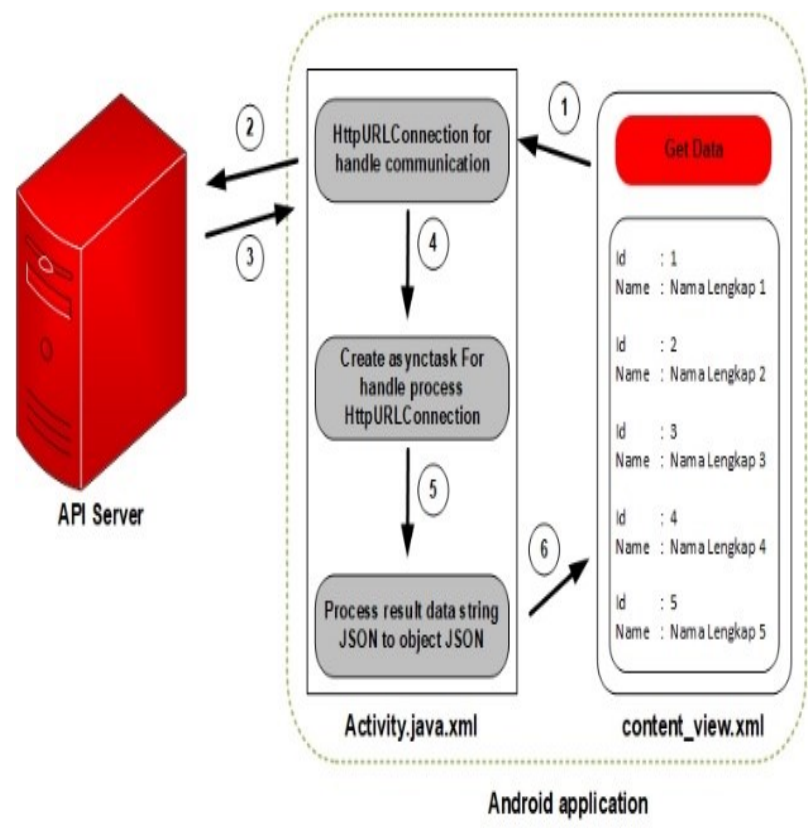

Gambar 3. Koneksi HttpURLConnection secara lengkap

Berikut adalah kode program yang digunakan untuk mengakses HttpURLConnection (Sufyan \& Banerjee, 2019). 


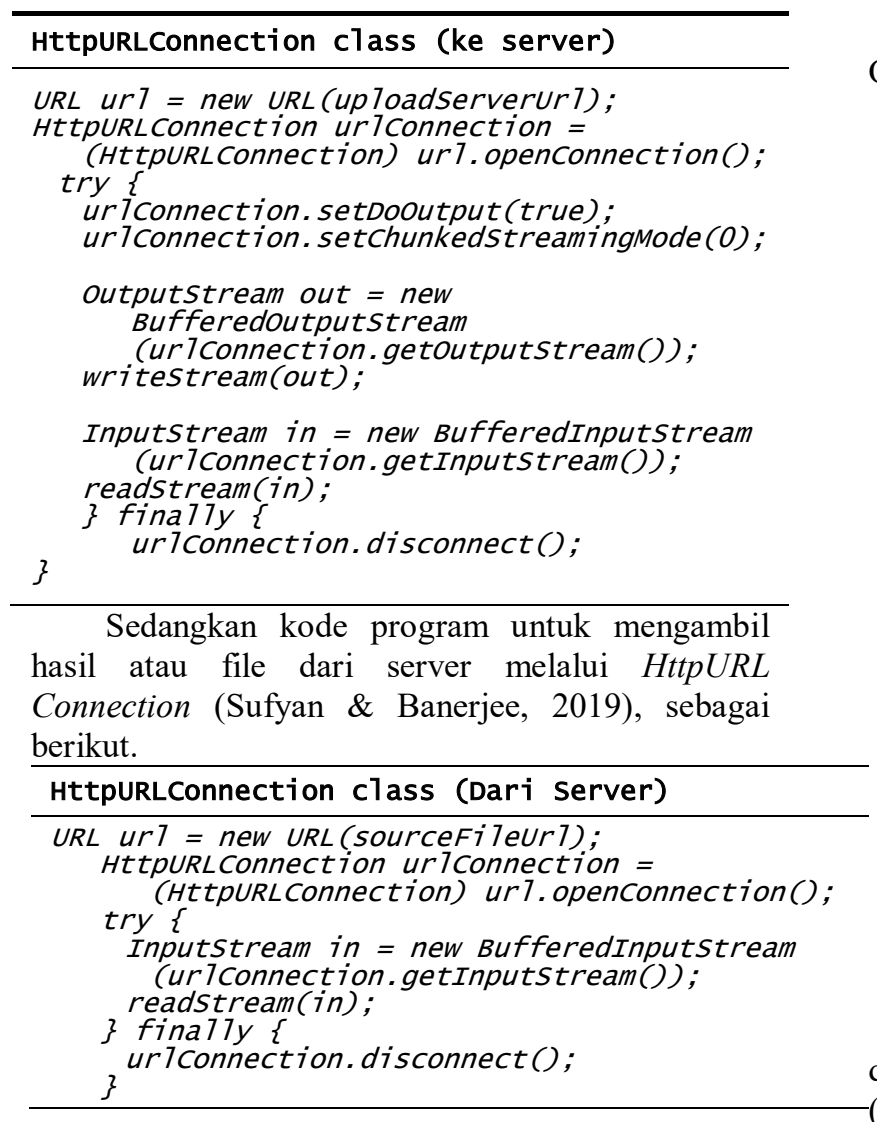

Langkah yang dilakukan dalam pembacaan QR-Code (Focardi et al., 2019).

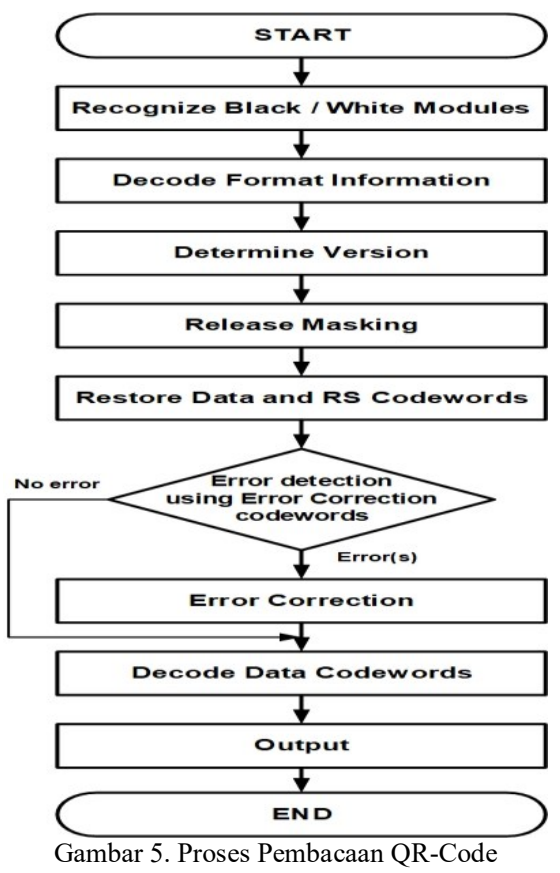

Sedangkan anatomi dari QR-Code yang digunakan aplikasi CyReborn sebagai berikut (Labolo, 2019).

\subsection{QR-Code}

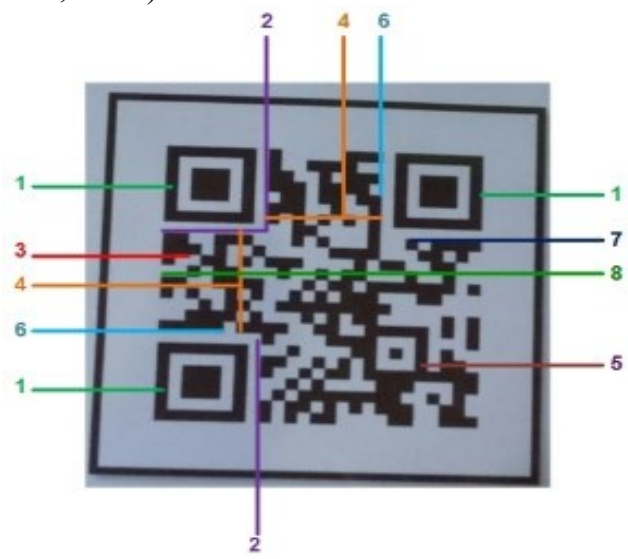

Gambar 6. Struktur QR-Code

Struktur QR-Code aplikasi CyReborn dapat dijelaskan sebagai berikut.

1. Finder Pattern digunakan untuk mengindentifikasi letak dari QR-Code yang digunakan pada aplikasi CyReborn.

2. Format Information digunakan untuk memberikan informasi mengenai error correction level dan mask pattern.

3. Data digunakan untuk menyimpan informasi yang dikodekan

4. Timing Patern digunakan untuk mengindentifikasi koordinat pusat.

5. Modul QR-Code yang berbentuk hitam dan putih.

6. Alignment Pattern adalah pola yang difungsikan sebagai perbaikan dari distorsi non linier penyimpangan QR-Code. 
7. Version Information digunakan sebagai informasi versi QR-Code yang digunakan.

8. Quiet Zone digunakan untuk memudahkan pengenalan terhadap daerah kosong dibagian terluar QR-Code.

\subsection{Sampel Populasi}

Jumlah populasi yang digunakan dalam penelitian ini menggunakan rumus slovin. Jumlah populasi sebanyak 248 orang mahasiswa, terdiri dari 182 orang calon mahasiswa jurusan Teknik Informatika, 22 orang calon mahasiswa jurusan Manajemen Informatika, dan 44 calon mahasiswa jurusan Komputerisasi Informatika. Untuk menghitung jumlah sampel, penelitian ini menggunakan rumus slovin, dengan rumus sebagai berikut (Rono, 2018).

$n=\frac{N}{1+N * e^{2}}$

Dimana :

$n=$ Jumlah sampel yang digunakan

$\mathrm{N}=$ Jumlah total populasi

$\mathrm{e}=$ Tingkat kesalahan / error

Jumlah total populasi sebanyak 248 peserta PKKMB, tingkat kesalahan sebesar 6,75\% dengan akurasi sebesar 93,25, maka jumlah sampel yang digunakan dalam penelitian ini.

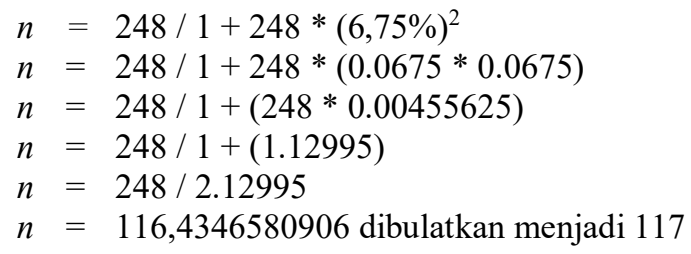

\section{HASIL DAN PEMBAHASAN}

Berikut adalah hasil yang diperoleh dari mengoptimalkan aplikasi CyReborn dengan HttpURLConnection API agar dapat mengeksekusi QRCode untuk memudahkan autentifikasi data peserta PKKMB baik absen masuk, absen istirahat maupun absen pulang dengan pemodelan perangkat lunak adalah Rapid Application Development (RAD)

\subsection{Pemodelan Sistem}

\subsubsection{Perencanaan Sistem}

Aplikasi CyReborn yang diimplementasikan merupakan aplikasi berbasis web framework untuk membantu dalam autentifikasi absensi data peserta PKKMB, hanya saja untuk menginputkan data peserta PKKMB ke dalam database, masih dilakukan secara manual. Sedangkan fokus penelitian ini ditujukan untuk mengoptimalkan kembali aplikasi CyReborn melalui implementasi HttpURLConnection API agar dapat menggunakan $Q R$-Code pada aplikasi Android, berikut kebutuhan sistem untuk mengoptimalisasi aplikasi CyReborn.

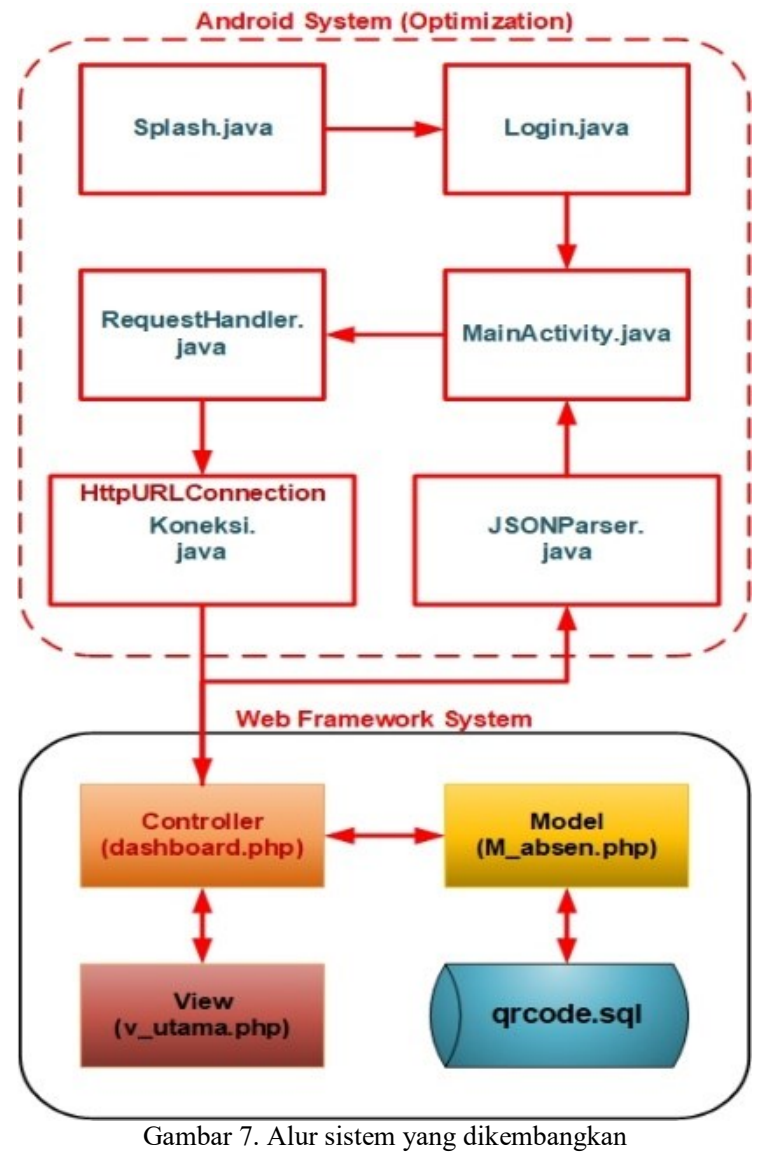

Pada gambar 7. diilustrasikan web framework system aplikasi CyReborn merupakan aplikasi yang dioptimalkan melalui Android System, agar dapat mengakses $Q R$-Code untuk memudahkan proses autentifikasi data peserta PKKMB.

\subsubsection{Pemodelan Aplikasi CyReborn}

Untuk memodelkan sistem aplikasi CyReborn, penelitian ini menggunakan tool unified modeling language (UML) dengan use case diagram untuk menggambarkan fungsionalitas sistem dengan aktor secara internal atau eksternal dari sistem (Wang, Fan, \& Pan, 2016). Perangkat lunak yang digunakan untuk memodelkan aplikasi CyReborn, berbasis online yaitu creately dari https://creately.com. Aktor yang terlibat dalam aplikasi CyReborn ada dua aktor yaitu Responsible Participants (Mentor) dan Admin System CyReborn Application. Aktor pertama berinteraksi dengan sistem dalam membuat QRCode, menyimpan QR-Code, autentifikasi absen masuk dan autentifikasi absen pulang. Sedangkan aktor kedua yaitu admin sistem aplikasi CyReborn, berinteraksi dengan sistem dalam menambah, mengedit, menghapus, dan mencetak berupa data absen, data peserta, data mentor, data pengguna, dan mengelola absen masuk dan absen pulang. Seperti yang diilustrasikan pada gambar berikut. 


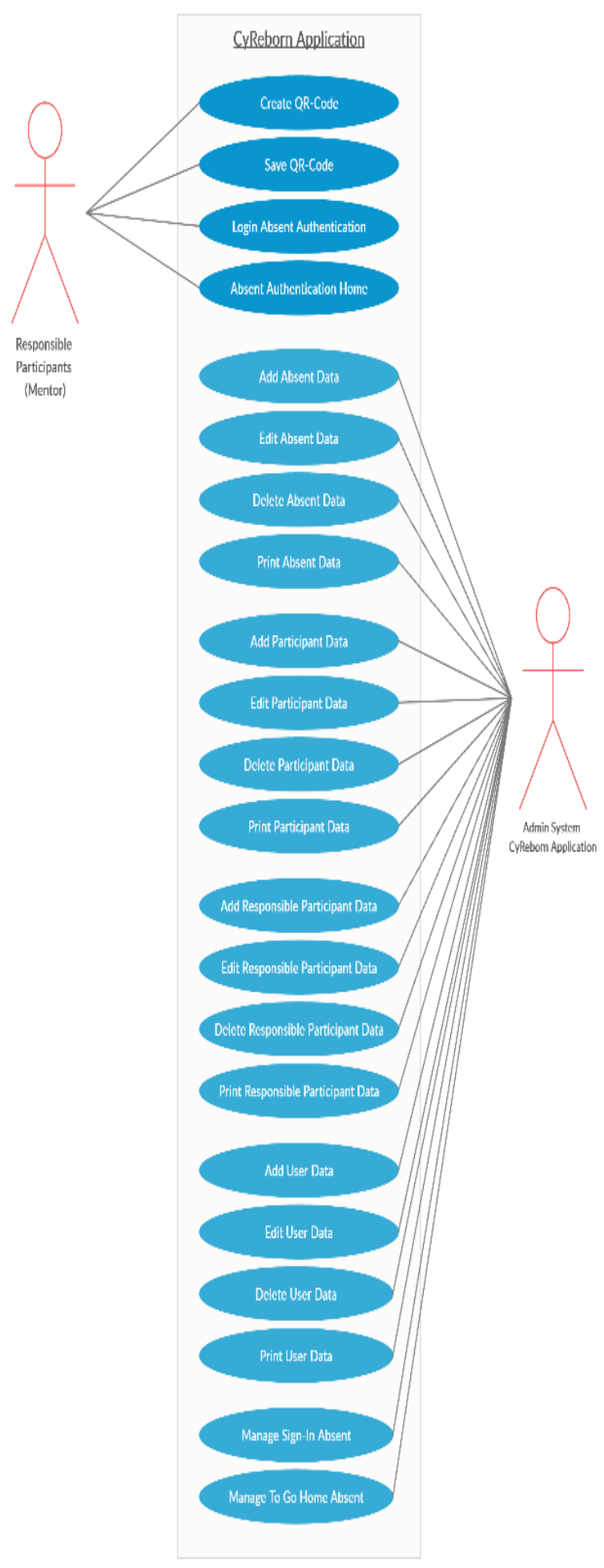

Gambar 8. Pemodelan Sistem Aplikasi CyReborn

\subsubsection{Alur Optimalisasi Aplikasi CyReborn}

Aplikasi CyReborn merupakan pengembangan dari aplikasi web framework dengan menambahkan HttpURLConnection sebagai penghubung antara aplikasi web framework dengan aplikasi android, untuk memudahkan autentifikasi data peserta PKKMB. Berikut alur hasil optimalisasi aplikasi CyReborn.
1. Peserta PKKMB membawa kartu peserta PKKMB, kemudian memberikannya kepada mentor yang bertugas untuk autentifikasi absen masuk dan absen pulang.

2. Panitia PKKMB memberikan autentifikasi data peserta yang sudah tersimpan didalam database server aplikasi CyReborn.

3. Panitia mendapatkan notifikasi berupa data peserta yang sudah tersimpan ke dalam database server aplikasi CyReborn.

4. Admin memantau peserta yang hadir dalam kegiatan PKKMB.

5. Admin dapat menambahkan, menghapus, dan mengedit data peserta PKKMB.

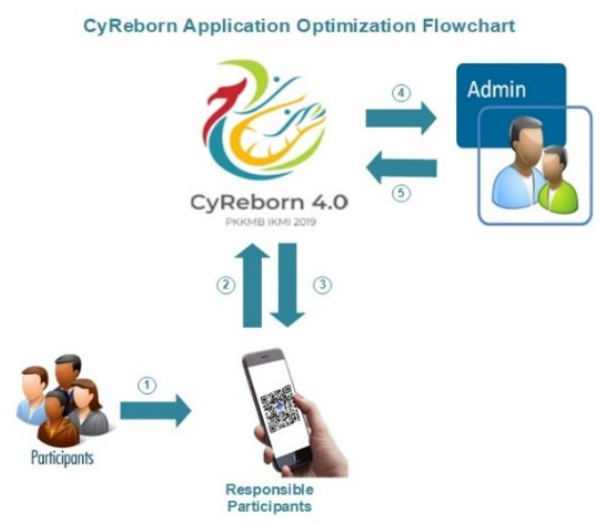

Gambar 9. Alur Optimalisasi Aplikasi CyReborn

\subsubsection{Pengujian Sistem Aplikasi CyReborn}

Berikut adalah hasil dari pengujian fungsional sistem aplikasi CyReborn.

Tabel 1 Pengujian Data Registrasi PKKMB

Kasus dan Hasil Uji Benar (Data Benar)

\begin{tabular}{|c|c|c|c|}
\hline Data Masukan & $\begin{array}{l}\text { Yang } \\
\text { Diharap } \\
\text { kan }\end{array}$ & Pengamatan & Kesimpulan \\
\hline $\begin{array}{l}\text { Mengisi data } \\
\text { registrasi PKKMB } \\
\text { contoh : } \\
\text { nama lengkap : Hari } \\
\text { Akbar Ramadhan } \\
\text { Alamat : } \\
\text { Majasem } \\
\text { Perjuangan Kota } \\
\text { Cirebon } \\
\text { Asal Sekolah : } \\
\text { SMKN 1 Cirebon } \\
\text { No HP } \\
\text { 0856958268xx } \\
\text { Kelompok: } \\
\text { Animator } \\
\text { Reguler : } \\
\text { Reguler Pagi }\end{array}$ & $\begin{array}{l}\text { Jika data } \\
\text { registrasi } \\
\text { valid, } \\
\text { maka data } \\
\text { peserta } \\
\text { tersimpan } \\
\text { kedalam } \\
\text { database } \\
\text { sekaligus } \\
\text { generate } \\
\text { QRCode. }\end{array}$ & $\begin{array}{l}\text { Data } \\
\text { registrasi } \\
\text { valid }\end{array}$ & Diterima \\
\hline \multicolumn{4}{|c|}{ Kasus dan Hasil Uji Salah (Data Salah) } \\
\hline Data Masukan & $\begin{array}{l}\text { Yang } \\
\text { Diharap } \\
\text { kan }\end{array}$ & Pengamatan & Kesimpulan \\
\hline $\begin{array}{l}\text { Nama lengkap, } \\
\text { alamat, asal } \\
\text { sekolah, no HP, } \\
\text { kelompok, reguler } \\
\text { belum diisi atau } \\
\text { salah }\end{array}$ & $\begin{array}{l}\text { Dapat } \\
\text { menampil- } \\
\text { kan pesan } \\
\text { kesalahan }\end{array}$ & $\begin{array}{l}\text { Menampil- } \\
\text { kan pesan } \\
\text { salah }\end{array}$ & Diterima \\
\hline
\end{tabular}




\subsection{Implementasi Aplikasi CyReborn}

Berikut tampilan halaman depan atau front end user dari aplikasi CyReborn hasil optimalisasi melalui HttpURLConnection berbasis Android. Pada gambar 10. halaman login digunakan untuk verifikasi pengguna yang akan menggunakan sistem, sedangkan pada gambar 11. halaman utama digunakan untuk memilih menu yang akan dieksekusi.

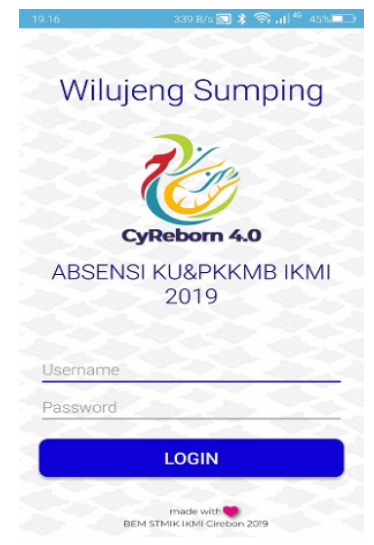

Gambar 10. Login Pengguna

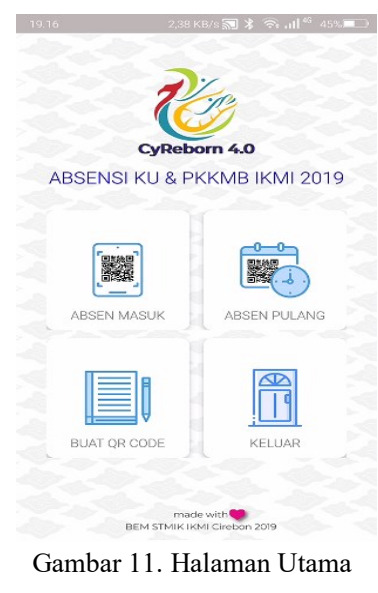

Sedangkan pada gambar 12. penanggung jawab peserta PKKMB melakukan pendataan biodata melalui halaman registrasi peserta dengan menekan tombol generate QR, hasilnya akan nampak pada gambar 13. biodata peserta PKKMB sudah diubah menjadi QR-Code, kemudian tombol simpan QRCode akan menyimpan biodata peserta PKKMB kedalam server aplikasi CyReborn.

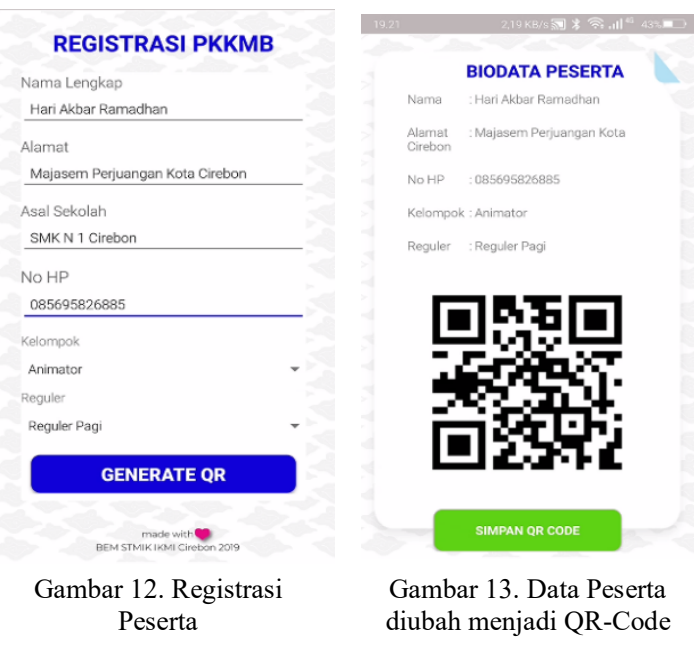

Untuk halaman belakang atau back end user dari aplikasi CyReborn hasil optimalisasi melalui HttpURLConnection berbasis web framework, administrator sistem harus melalui halaman login untuk mengeksekusi halaman lainnya, seperti yang diilustrasikan pada gambar 14 ..

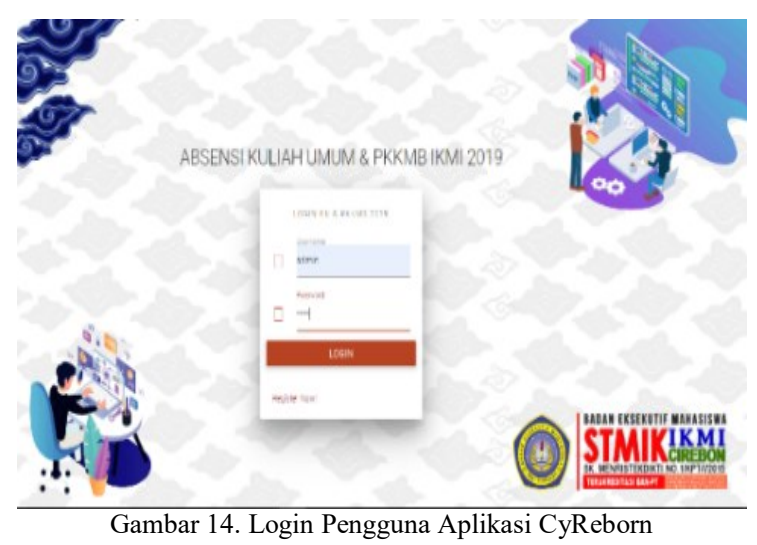

Sedangkan untuk mengelola absen masuk dan absen pulang, seorang administrator sistem harus mengeksekusi halaman rekap absen aplikasi CyReborn yang autentifikasi absensinya dilakukan melalui front end user berbasis android pada pembahasan sebelumnya.

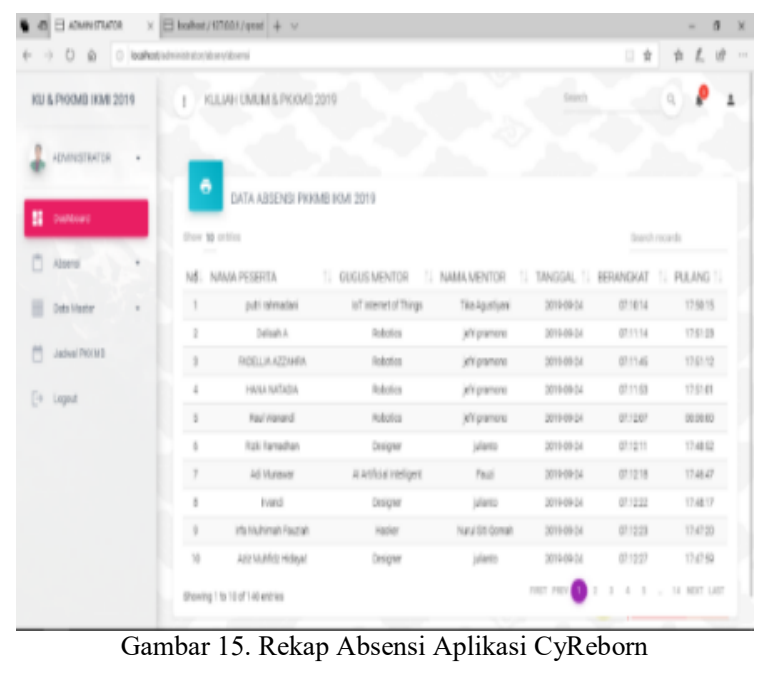

\subsection{Pengujian Optimalisasi Aplikasi CyReborn}

Pengujian optimalisasi terhadap aplikasi CyReborn terutama pada proses autentifikasi dengan melibatkan peserta sebanyak 117 dari 248 orang peserta dengan tingkat akurasi 93,25\% (Rono, 2018). Pengujian menggunakan 4 (empat) buah API yang banyak digunakan aplikasi android dan web php (Ferryansyah, Ananta, \& Fanani, 2017), diantaranya HttpURLConnection, Retrofit, OkHttp dan Asynchronous Http Client. Berikut hasil pengujian atau eksperimen terhadap masing-masing API.

\subsubsection{Pengujian Dengan HttpURLConnection API}

Hasil pengujian aplikasi CyReborn dengan metode HttpURLConnection API, sebagai berikut.

Tabel 2 Hasil Optimalisasi Dengan HttpURLConnection API

\begin{tabular}{clccc}
\hline Id & \multicolumn{1}{c}{ Nama Peserta } & $\begin{array}{c}\text { Hasil } \\
\text { Awal } \\
\text { (detik) }\end{array}$ & $\begin{array}{c}\text { Hasil } \\
\text { Akhir } \\
\text { (detik) }\end{array}$ & $\begin{array}{c}\text { Gap } \\
\text { (detik) }\end{array}$ \\
\hline 1 & $\begin{array}{l}\text { Fian Sayful } \\
\text { Romansyah }\end{array}$ & 40 & 10 & 30 \\
2 & Agung Faisal & 30 & 8 & 22 \\
\hline
\end{tabular}




\begin{tabular}{clccc}
\hline Id & Nama Peserta & $\begin{array}{c}\text { Hasil } \\
\text { Awal } \\
\text { (detik) }\end{array}$ & $\begin{array}{c}\text { Hasil } \\
\text { Akhir } \\
\text { (detik) }\end{array}$ & $\begin{array}{c}\text { Gap } \\
\text { (detik) }\end{array}$ \\
\hline 3 & Mohamad Ruchiat & 60 & 10 & 50 \\
4 & Zhurufy Rahmany & 30 & 7 & 23 \\
5 & Lutfi Fajaryadi & 30 & 8 & 22 \\
6 & Sopyan & 35 & 10 & 25 \\
7 & Fikmi Ikmiah & 60 & 8 & 52 \\
8 & Hana Rosyani & 40 & 9 & 31 \\
9 & Muhammad Jafar & 50 & 10 & 40 \\
10 & Ichsanudin Masyuri & 30 & 10 & 20 \\
. & .. &.. &.. &.. \\
117 & Azhar Al Afghani & 60 & 10 & 50 \\
\hline
\end{tabular}

Tabel 2 merupakan hasil pengujian aplikasi CyReborn dengan HttpURLConnection, diperoleh hasil pengujian kecepatan autentifikasi awal aplikasi tanpa QRCode dengan hasil pengujian kecepatan autentifikasi akhir aplikasi dengan QRCode. Sedangkan HttpURLConnection digunakan untuk menghubungkan aplikasi android dengan web framework. Gap merupakan jarak kecepatan antara sebelum optimalisasi dan sesudah optimalisasi aplikasi CyReborn. Satuan yang digunakan dalam pengujian pada tabel 2 adalah detik. Hasil pengujian aplikasi CyReborn dengan HttpURL Connection $A P I$, dapat diilustrasikan pada gambar 16 berikut ini.

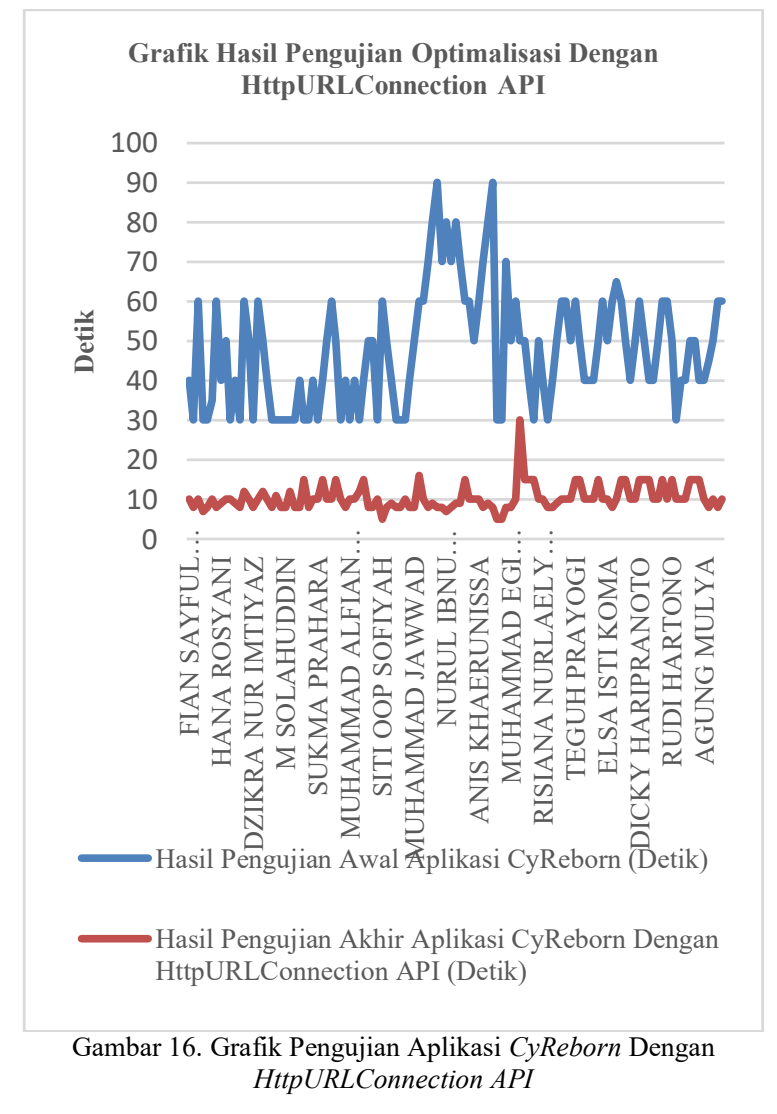

\subsubsection{Pengujian Dengan Retrofit API}

Hasil pengujian aplikasi CyReborn dengan metode Retrofit API, sebagai berikut.

\begin{tabular}{|c|c|c|c|c|}
\hline Id & Nama Peserta & $\begin{array}{c}\text { Hasil } \\
\text { Awal } \\
\text { (detik) }\end{array}$ & $\begin{array}{l}\text { Hasil } \\
\text { Akhir } \\
\text { (detik) }\end{array}$ & $\underset{\text { (detik) }}{\text { Gap }}$ \\
\hline 1 & $\begin{array}{l}\text { Fian Sayful } \\
\text { Romansyah }\end{array}$ & 40 & 12 & 28 \\
\hline 2 & Agung Faisal & 30 & 10 & 20 \\
\hline 3 & Mohamad Ruchiat & 60 & 13 & 47 \\
\hline 4 & Zhurufy Rahmany & 30 & 10 & 20 \\
\hline 5 & Lutfi Fajaryadi & 30 & 11 & 19 \\
\hline 6 & Sopyan & 35 & 13 & 22 \\
\hline 7 & Fikmi Ikmiah & 60 & 12 & 48 \\
\hline 8 & Hana Rosyani & 40 & 14 & 26 \\
\hline 9 & Muhammad Jafar & 50 & 13 & 37 \\
\hline 10 & Ichsanudin Masyuri & 30 & 13 & 17 \\
\hline$\cdot$ &.. &.. &.. &.. \\
\hline 117 & Azhar Al Afghani & 60 & 13 & 47 \\
\hline
\end{tabular}

Hasil pengujian yang disajikan dalam tabel 4.3 menunjukan sedikit perbedaan antara hasil pengujian aplikasi CyReborn dengan HttpURLConnection API, sedangkan data hasil pengujian kecepatan awal masih menggunakan data yang sama, karena pengujian hanya difokuskan pada penerapan metode Retrofit API. Satuan yang digunakan dalam pengujian pada tabel 3 adalah detik. Hasil pengujian aplikasi CyReborn dengan Retrofit API, dapat diilustrasikan pada gambar 4.11 berikut ini.

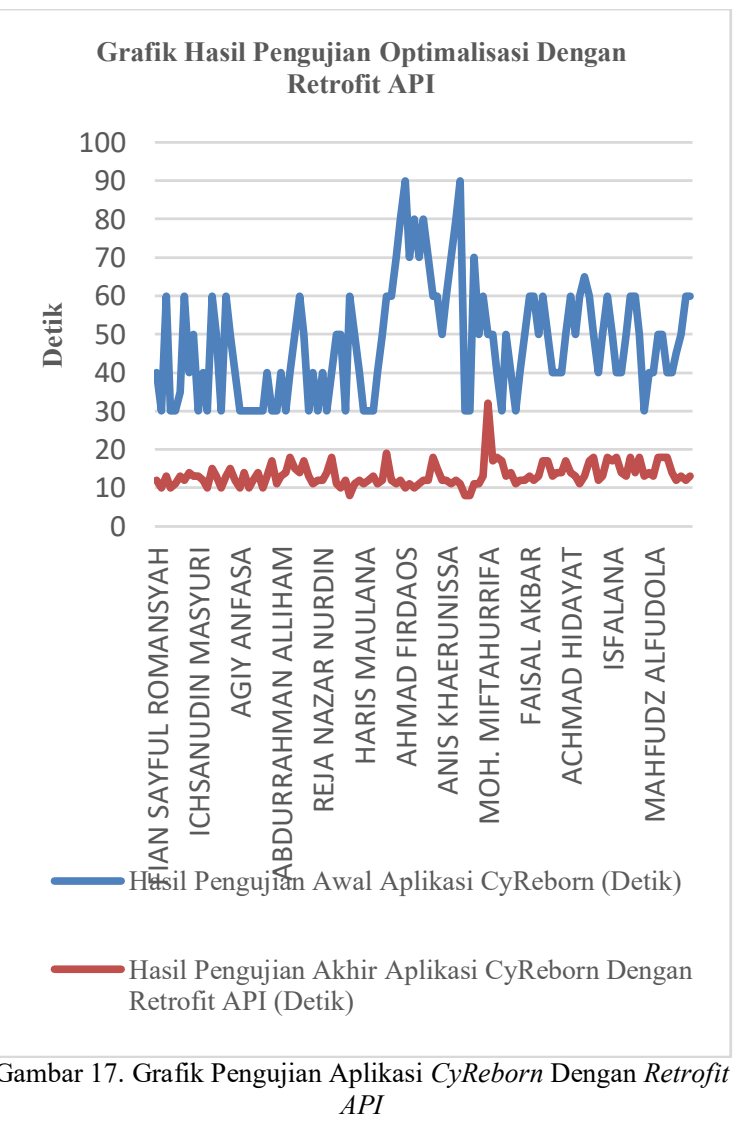

\subsubsection{Pengujian Dengan OkHttp API}

Hasil pengujian aplikasi CyReborn dengan metode OkHttp API, sebagai berikut. 
504 Jurnal Teknologi Informasi dan Ilmu Komputer (JTIIK), Vol. 8, No. 3, Juni 2021, hlm. 495-508

\begin{tabular}{|c|c|c|c|c|}
\hline Id & Nama Peserta & $\begin{array}{c}\text { Hasil } \\
\text { Awal } \\
\text { (detik) }\end{array}$ & $\begin{array}{l}\text { Hasil } \\
\text { Akhir } \\
\text { (detik) }\end{array}$ & $\begin{array}{c}\text { Gap } \\
\text { (detik) }\end{array}$ \\
\hline 1 & $\begin{array}{l}\text { Fian Sayful } \\
\text { Romansyah }\end{array}$ & 40 & 14 & 26 \\
\hline 2 & Agung Faisal & 30 & 12 & 18 \\
\hline 3 & Mohamad Ruchiat & 60 & 15 & 45 \\
\hline 4 & Zhurufy Rahmany & 30 & 12 & 18 \\
\hline 5 & Lutfi Fajaryadi & 30 & 13 & 17 \\
\hline 6 & Sopyan & 35 & 15 & 20 \\
\hline 7 & Fikmi Ikmiah & 60 & 13 & 47 \\
\hline 8 & Hana Rosyani & 40 & 15 & 25 \\
\hline 9 & Muhammad Jafar & 50 & 14 & 36 \\
\hline 10 & Ichsanudin Masyuri & 30 & 14 & 16 \\
\hline . &.. &.. &.. &.. \\
\hline 117 & Azhar Al Afghani & 60 & 14 & 46 \\
\hline
\end{tabular}

Tabel 4 menunjukan hasil pengujian yang menunjukan perbedaan besar antara pengujian aplikasi CyReborn dengan HttpURLConnection API dengan OkHttp API, sedangkan data hasil pengujian kecepatan autentifikasi awal masih menggunakan data yang sama, karena pengujian difokuskan pada penerapan metode OkHttp API. Satuan yang digunakan dalam pengujian pada tabel 3 adalah detik.Hasil pengujian aplikasi CyReborn dengan OkHttp API, dapat diilustrasikan pada gambar 4.12.

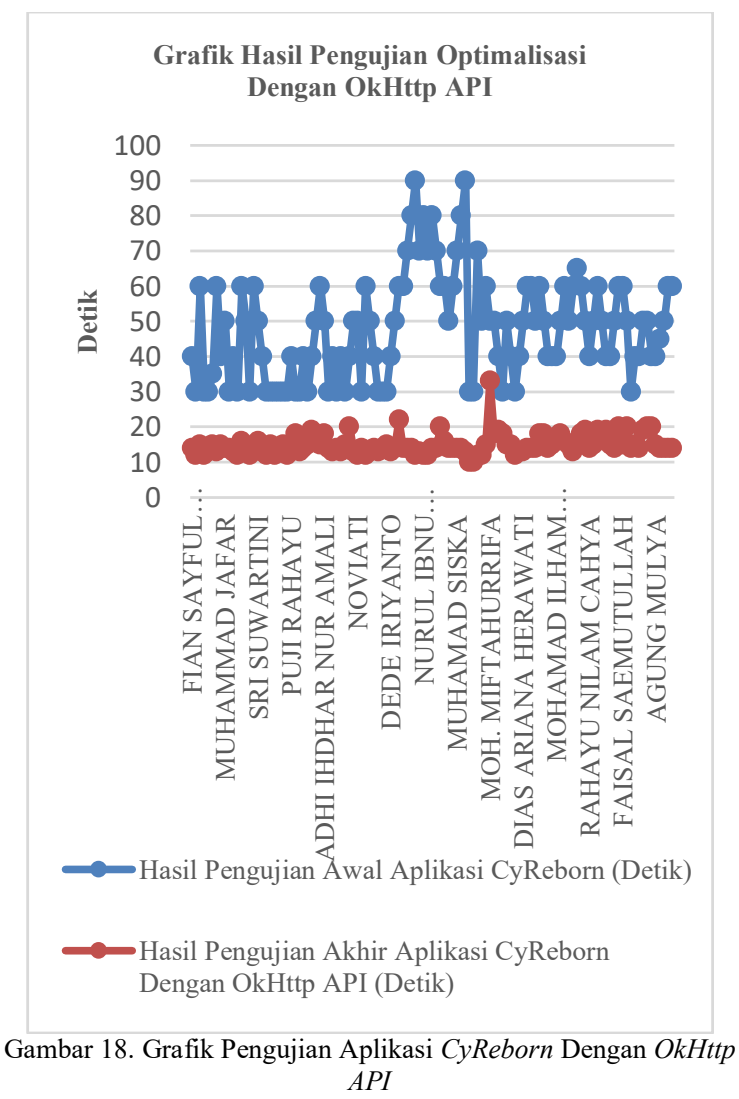

\subsubsection{Pengujian Dengan Asynchronous API}

Hasil pengujian aplikasi CyReborn dengan metode Asynchronous Http Client API, sebagai berikut.

Tabel 5 Hasil Pengujian Dengan Asynchronous Http Client API

\begin{tabular}{clccc}
\hline Id & \multicolumn{1}{c}{ Nama Peserta } & $\begin{array}{c}\text { Hasil } \\
\text { Awal } \\
\text { (detik) }\end{array}$ & $\begin{array}{c}\text { Hasil } \\
\text { Akhir } \\
\text { (detik) }\end{array}$ & $\begin{array}{c}\text { Gap } \\
\text { (detik) }\end{array}$ \\
\hline 1 & Fian Sayful & 40 & 15 & 25 \\
2 & Romansyah & 30 & 13 & 17 \\
3 & Agung Faisal & 60 & 16 & 44 \\
4 & Mohamad Ruchiat & 30 & 13 & 17 \\
5 & Lutfi Fajaryadi & 30 & 15 & 15 \\
6 & Sopyan & 35 & 16 & 19 \\
7 & Fikmi Ikmiah & 60 & 14 & 46 \\
8 & Hana Rosyani & 40 & 15 & 25 \\
9 & Muhammad Jafar & 50 & 15 & 35 \\
10 & Ichsanudin Masyuri & 30 & 15 & 15 \\
. & .. &.. &.. &.. \\
117 & Azhar Al Afghani & 60 & 14 & 46 \\
\hline
\end{tabular}

Hasil pengujian yang disajikan pada tabel 5 menunjukan perbedaan yang cukup lebih besar antara pengujian aplikasi CyReborn dengan Http URLConnection API dengan Asynchronous Http Client, sedangkan data hasil pengujian kecepatan autentifikasi awal masih menggunakan data yang sama, karena pengujian hanya difokuskan pada penerapan metode Asynchronous Http Client API. Satuan yang digunakan dalam pengujian pada tabel 5 adalah detik. Hasil pengujian aplikasi CyReborn dengan Asynchronous Http Client API, diilustrasikan pada gambar 4.13 .

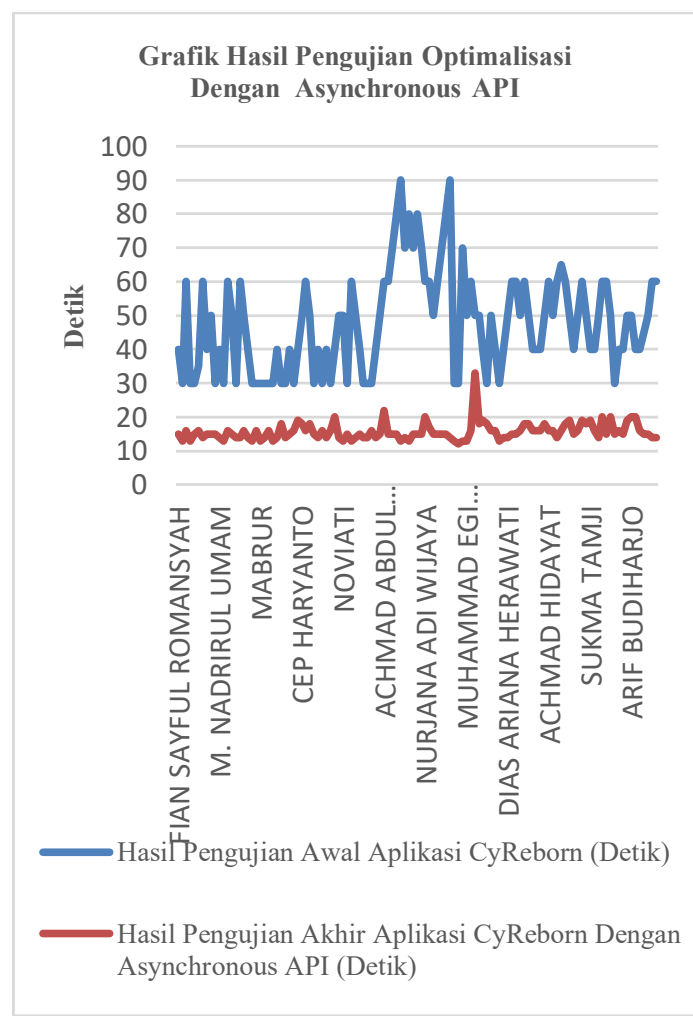

Gambar 19. Grafik Pengujian Aplikasi CyReborn Dengan Asynchronous Http Client API 


\subsection{Pembahasan}

Berdasarkan hasil eksperimen yang dilakukan pada tabel 2, tabel 3, tabel 4 dan tabel 5 diatas, kemudian diambil hasil pengujian tertinggi dan hasil pengujian terendah untuk hasil akhir optimalisasi aplikasi CyReborn serta gap antara hasil pengujian awal sebelum dilakukan optimalisasi dengan sesudah dilakukan optimalisasi, seperti pada tabel 6 .

Tabel 6 Hasil Pengujian Optimalisasi Aplikasi CyReborn

\begin{tabular}{lcccc}
\hline Metode API & $\begin{array}{c}\text { Hasil } \\
\text { Akhir } \\
\text { Terendah } \\
\text { (detik) }\end{array}$ & $\begin{array}{c}\text { Hasil } \\
\text { Akhir } \\
\text { Tertinggi } \\
\text { (detik) }\end{array}$ & $\begin{array}{c}\text { Gap } \\
\text { Terendah } \\
\text { (detik) }\end{array}$ & $\begin{array}{c}\text { Gap } \\
\text { Tertinggi } \\
\text { (detik) }\end{array}$ \\
\hline $\begin{array}{l}\text { HttpURL } \\
\text { Connection }\end{array}$ & 5 & 30 & 15 & 82 \\
Retrofit & 8 & 32 & 13 & 80 \\
OkHttp & 10 & 33 & 12 & 78 \\
Asynchronous & 12 & 33 & 12 & 77 \\
Http Client & 12 & & & \\
\hline
\end{tabular}

Hasil akhir pengujian optimalisasi aplikasi CyReborn dengan HttpURLConnection diperoleh hasil akhir terendah 5 detik dan gap terendah 15 detik pada tabel 2, sedangkan hasil akhir tertinggi 30 detik dan gap tertinggi 82 detik pada tabel 2 . Kemudian retrofit hasil akhir terendah 8 detik dan gap terendah 13 detik pada tabel 3, sedangkan hasil akhir tertinggi 32 detik dan gap tertinggi 82 detik pada tabel 3. Untuk OkHttp hasil akhir terendah 10 detik dan gap terendah 12 detik pada tabel 4, sedangkan hasil akhir tertinggi 33 detik dan gap tertinggi 78 detik pada tabel 4. Dan Asynchronous Http Client hasil akhir terendah 12 detik dan gap terendah 33 detik pada tabel 5, sedangkan hasil akhir tertinggi 12 detik dan gap tertinggi 77 detik pada tabel 5 .

Perbedaan kecepatan pada proses autentifikasi tersebut disebabkan karena pada saat penginputan awal aplikasi CyReborn diinputkan melalui keyboard yang ada pada laptop atau personal komputer atau PC, sehingga penginputan data dipengaruhi oleh kecepatan pengetikkan oleh sepuluh orang pendamping peserta. Sedangkan pengujian akhir aplikasi CyReborn, proses autentifikasi dilakukan dengan penginputan secara otomatis melalui $Q R$ Code dari aplikasi Android yang dimiliki oleh masing-masing pendamping, sehingga penginputan data tidak lagi dipengaruhi oleh kecepatan pengetikkan pendamping peserta akan tetapi secara otomatis dilakukan QR-Code yang dipengaruhi oleh keempat API yang biasa digunakan dalam aplikasi android dan framework PHP, yaitu HttpURLConnection, Retrofit, OkHttp dan Asynchronous Http Client.

Kemudian pada tabel 6 hasil perbandingan keempat metode yang biasa digunakan oleh aplikasi android dan framework PHP, membuktikan bahwa hasil pengujian optimalisasi aplikasi CyReborn dengan HttpURLConnection memiliki keunggulan dibandingkan Retrofit, OkHttp, dan Asynchronous
Http Client, disemua pengujian baik pada hasil akhir optimalisasi terendah maupun tertinggi, disamping penggunaan memory yang kecil terutama teks (Ferryansyah, Ananta, \& Fanani, 2017). Sedangkan untuk perbandingan gap antara aplikasi CyReborn dengan HttpURLConnection memiliki gap tertinggi dibandingkan Retrofit, OkHttp, dan Asynchronous Http Client, disemua pengujian baik pada hasil akhir optimalisasi terendah maupun tertinggi yang artinya aplikasi CyReborn dengan HttpURLConnection memiliki kecepatan perekaman data lebih baik dibandingkan Retrofit, OkHttp, dan Asynchronous Http Client. Hasil pengujian keempat metode pada tabel 6, diilustrasikan pada gambar 20 .

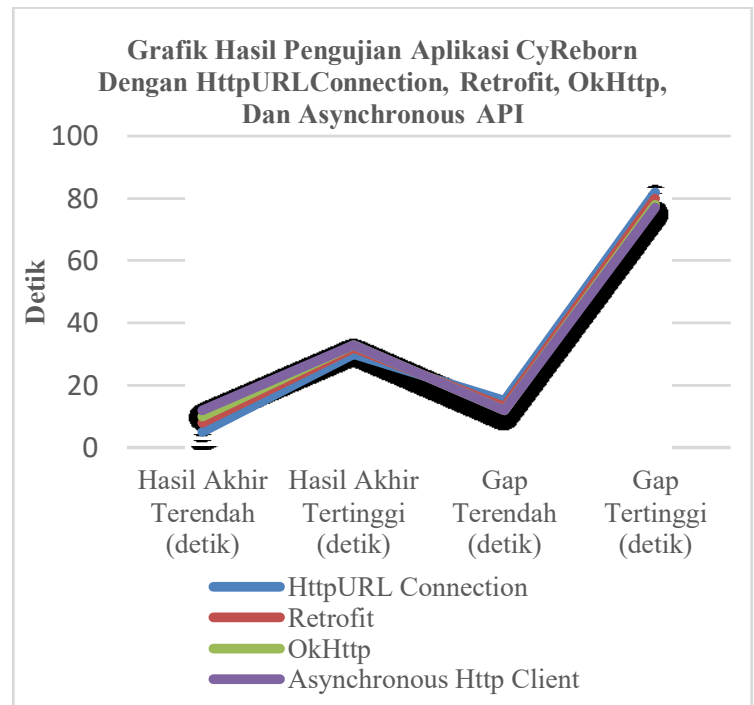

Gambar 20.Grafik Perbedaan Hasil Pengujian Aplikasi CyReborn dengan keempat metode $A P I$

Kemudian hasil dari tabel 6 diubah atau dikonversi kedalam prosentase, sehingga dihasilkan pada tabel 7 berikut ini.

Tabel 7 Gap Prosentase Hasil Pengujian Optimalisasi Aplikasi CyReborn

\begin{tabular}{lcc} 
Metode API & $\begin{array}{c}\text { Gap Persentase } \\
\text { Terendah (\%) }\end{array}$ & $\begin{array}{c}\text { Gap Persentase } \\
\text { Tertinggi }(\%)\end{array}$ \\
\hline $\begin{array}{l}\text { HttpURL } \\
\text { Connection }\end{array}$ & 40 & 92 \\
$\begin{array}{l}\text { Retrofit } \\
\text { OkHttp }\end{array}$ & 36 & 89 \\
$\begin{array}{l}\text { Asynchronous } \\
\text { Http Client }\end{array}$ & 34 & 87 \\
\hline
\end{tabular}

Tabel 7 menunjukkan bahwa gap hasil konversi pengujian aplikasi CyReborn sebelum dilakukan optimalisasi dengan sesudah optimalisasi terutama dengan metode HttpURLConnection API dari satuan detik (tabel 6) kedalam persentase menghasilkan prosentase tertinggi yaitu $40 \%$ untuk persentase hasil pengujian terendah dan $92 \%$ untuk persentase pengujian tertinggi dibandingkan dengan metode 
Retrofit API, OkHttp API, dan Asynchronous Http Client API, bergantung aspek kecepatan pengetikkan, banyaknya karakter nama peserta, dan lebar bandwidth yang digunakan pada saat pengujian. Hasil pengujian dengan satuan persentase dari keempat metode pada tabel 7 , diilustrasikan pada gambar 21 .

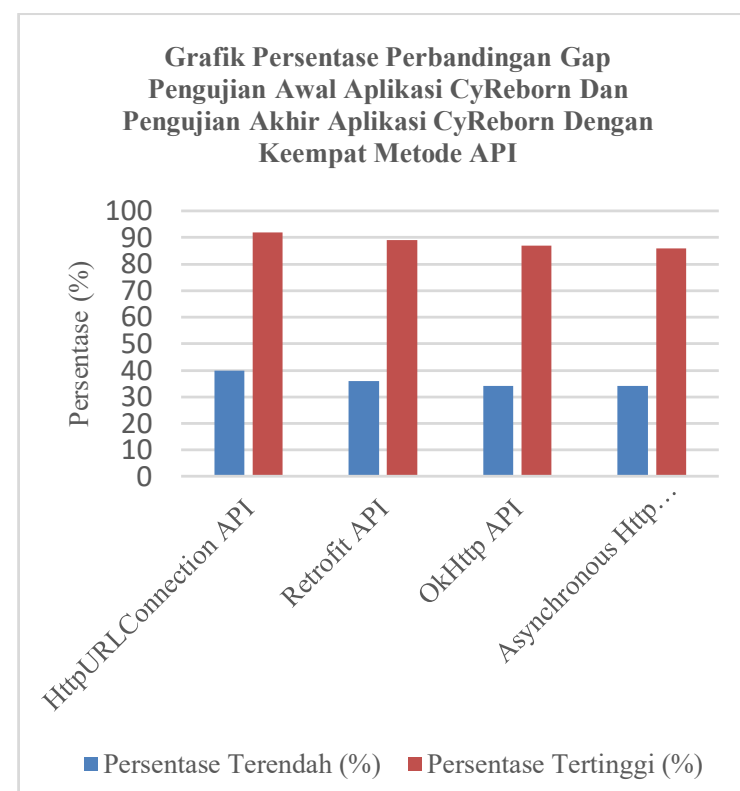

Gambar 21. Grafik Perbedaan Hasil Pengujian Aplikasi CyReborn dengan keempat metode $A P I$ dalam persentase

Hasil pengujian optimalisasi yang dilakukan terhadap aplikasi CyReborn terutama pada proses autentifikasi, dapat mengurangi penumpukan antrian peserta PKKMB terutama pada saat absen pagi, siang, dan pulang. Sehingga hasil dari penelitian ini dapat di rekomendasikan atau sumbangan terhadap ilmu pengetahuan terutama dalam mencari metode yang tepat untuk dikembangkan pada aplikasi berbasis PHP web framework dengan android.

\section{KESIMPULAN}

Dari hasil eksperimen atau pengujian optimalisasi aplikasi CyReborn dengan 4 (empat) buah API yang digunakan aplikasi android dan web php, terbukti bahwa HttpURLConnection memiliki keunggulan dibandingkan dengan metode Retrofit API, OkHttp API dan Asynchronous Http Client API terutama kecepatan dalam perekaman data peserta PKKMB kedalam server dengan QRCode berbasis aplikasi android dengan data sebanyak 117 dari 248 peserta PKKMB, hasil pengujian juga dapat menguraikan padatnya antrian peserta PKKMB terutama pada saat autentifikasi absensi pagi, absensi siang atau istirahat, dan absensi pulang. Untuk hasil akhir terendah 5 detik dan hasil akhir tertinggi 30 detik, dengan gap terendah 15 detik dan tertinggi 82 , sedangkan gap persentase terendah sebesar $40 \%$ dan gap tertinggi $92 \%$.

\section{UCAPAN TERIMA KASIH}

Seluruh peserta dan panitia PKKMB STMIK IKMI Cirebon tahun 2019.

\section{DAFTAR PUSTAKA}

ANDRI. 2019. Penerapan Algoritma Pencarian Binary Search dan QuickSort pada Aplikasi Kamus Bahasa Palembang Berbasis Web. Jurnal Informatika: Jurnal Pengembangan IT (JPIT), 04(01), 70-74. https://doi.org/10.30591/jpit.v4i1.1104

AZHAR, M. A., SAUDI, M. M., AHMAD, A., \& ABU BAKAR, A. 2019. Detection of social media exploitation via SMS and camera. International Journal of Interactive Mobile Technologies, 13(4), 61-78. https://doi.org/10.3991/IJIM.V13I04.10521

FAQIH, A. H., LAKSANA, T. G., \& FEBRIATI, A. 2018. Sistem informasi reporting curiculum vitae karyawan menggunakan metode rapid application development berbasis website di PT. PINS Indonesia. JIPI (Jurnal Ilmiah Penelitian dan Pembelajaran Informatika), 03, 69-75.

FERRYANSYAH, M. S., ANANTA, M. T., \& FANANI, L. 2017. Analisis Performansi HTTP Networking Library pada Android ( Studi Kasus: Portal Berita ). Jurnal Pengembangan Teknologi Informasi dan Ilmu Komputer, 2(5), 2025-2033.

FOCARDI, R., LUCCIO, F. L., \& WAHSHEH, H. A. M. 2019. Usable security for QR code. Journal of Information Security and Applications, $\quad 48, \quad 102369$. https://doi.org/10.1016/j.jisa.2019.102369

GRACIA, J., \& BAYO, E. 2018. An effective and user-friendly web application for the collaborative analysis of steel joints. Advances in Engineering Software, 119(March 2017), 60-67.

https://doi.org/10.1016/j.advengsoft.2018.02.0 07

LABOLO, I. 2019. Implementasi QRCode Untuk Absensi Perkuliahan Mahasiswa Berbasis Paperless Office. Jurnal Informatika UPGRIS, 5(1), 1-4.

PARMAR, R., PATEL, T., AGRAWAL, S., \& VERMA, J. 2018. Towards Benchmarking Android Networking Libraries. International Journal of Engineering Research in Computer Science and Engineering (IJERCSE), 5(3), 323-325.

PERMANA, A. P., NURHAYANTI, O. D., \& MARTONO, K. T. 2016. Perancangan dan Implementasi Augmented Reality Pemantauan Titik Reklame Kota Semarang Menggunakan QR-Code Berbasis ANDROID. Jurnal 
Teknologi dan Sistem Komputer, 4(2), 295304.

PROKOFYEVA, N., \& BOLTUNOVA, V. 2017. Analysis and Practical Application of PHP Frameworks in Development of Web Information Systems. Procedia - Procedia Computer Science, 104(December 2016), 5156. https://doi.org/10.1016/j.procs.2017.01.059

RONO, L. DAISY CHELANGAT. 2018. Microcredit and Its Relationship To the Growth of Small and Medium Enterprises in Konoin Subcounty, Kenya. International Journal of Advanced Research, 6(4), 961-968. https://doi.org/10.21474/ijar01/6935

SUFYAN, F., \& BANERJEE, A. 2019. Comparative analysis of network libraries for offloading efficiency in mobile cloud environment. International Journal of Advanced Computer Science and Applications, 10(2), 574-584. https://doi.org/10.14569/ijacsa.2019.0100272

SUNARDI, A., \& SUHARJITO. 2019. MVC Architecture: A Comparative Study Between Laravel Framework and Slim Framework in Freelancer Project Monitoring System Web Based. Procedia Computer Science, 157, 134 141

https://doi.org/10.1016/j.procs.2019.08.150

SUPRIYATMAN, SUHANDI, A., RUSDIANA, D., SAMSUDIN, A., WIBOWO, F. C., \& MANSYUR, J. 2018. Design of Experimental Problem Solving-Based Learning Program to Improve Mental Model and to Enhance Mental-Modeling Ability. Jurnal Pendidikan Fisika Indonesia, 14(July), 73-82. https://doi.org/10.15294/jpfi.v14i2.6279

WANG, C. J., FAN, H. J., \& PAN, S. 2016. Research on Mapping UML to Petri-Net in System Modeling. EDP Sciences, 38(61473306), 2-5. 
Halaman ini sengaja dikosongkan 